Short communication

\title{
Characterization of biogenic phosphorus in sediments from the multi-polluted Haihe River, China, using phosphorus fractionation and ${ }^{31} \mathrm{P}-\mathrm{NMR}$
}

\author{
Wenqiang Zhang a,b, Wenzhong Tang ${ }^{\mathrm{a}}$, Hong Zhang ${ }^{\mathrm{a}}$, Jianlin $\mathrm{Bi}^{\mathrm{c}}$, Xin Jin ${ }^{\mathrm{d}}$, \\ Jie Li ${ }^{\mathrm{a}}$, Baoqing Shan ${ }^{\mathrm{a}, *}$ \\ a State Key Laboratory on Environmental Aquatic Chemistry, Research Center for Eco-Environmental Science, Chinese Academy of Science, Beijing 100085, \\ China \\ b University of Chinese Academy of Science, Beijing 100049, China

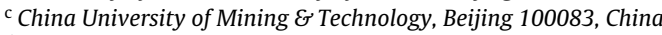 \\ ${ }^{\mathrm{d}}$ Hebei University of Engineering, Handan, Hebei 056038, China
}

\section{A R T I C L E I N F O}

\section{Article history:}

Received 17 January 2014

Received in revised form 22 June 2014

Accepted 20 July 2014

Available online 16 August 2014

\section{Keywords:}

Phosphorus

River

Sediment

Fractionation

${ }^{31} \mathrm{P}-\mathrm{NMR}$

\begin{abstract}
A B S T R A C T
We studied the phosphorus $(\mathrm{P})$ pollution, as described by concentrations, distribution and transformation potential, of sediments of the water scarce and heavily polluted Fuyang River, a tributary of the Haihe River, using $\mathrm{P}$ fractionation and phosphorus-31 nuclear magnetic resonance ( $\left.{ }^{31} \mathrm{P}-\mathrm{NMR}\right)$. In terms of their contribution to total $\mathrm{P}$, the rank order of the $\mathrm{P}$ fractions was as follows: $\mathrm{H}_{2} \mathrm{SO}_{4}-\mathrm{P}>\mathrm{NaOH}-\mathrm{Pi}>\mathrm{Res}-$ $\mathrm{P}>\mathrm{NaOH}-\mathrm{Po}>\mathrm{KCl}-\mathrm{P}$. Seven $\mathrm{P}$ compounds were detected by the ${ }^{31} \mathrm{P}-\mathrm{NMR}$ analysis. Orthophosphate (45.2-92.4\%) and orthophosphate monoesters (6.6-45.7\%) were the dominant forms. Smaller amounts of pyrophosphates $(0.1-6.6 \%)$, deoxyribonucleic acid $(0.3-3.9 \%)$, phosphonates $(0-3.3 \%)$, phospholipids $(0-2.7 \%)$ and polyphosphates $(0-0.04 \%)$ were observed in the sediments. Results of $\mathrm{P}$ fractionation and ${ }^{31} \mathrm{P}-\mathrm{NMR}$ analysis showed that $35 \%$ of $\mathrm{Pi}$ was labile $\mathrm{P}$, including $\mathrm{KCl}-\mathrm{P}$ and $\mathrm{NaOH}-\mathrm{Pi}$ (Fe-P and $\mathrm{Al}-\mathrm{P}$ ). Biogenic-P accounted for $24 \%$ of $P$ in the sediments. Analysis of the relationships between $\mathrm{P}$ species and water quality indicated that the Po compounds would mineralize to form ortho-P and would be potentially bioavailable for recycling to surface water, supporting further growth of phytoplankton and leading to algal blooms.
\end{abstract}

(C) 2014 Elsevier B.V. All rights reserved.

\section{Introduction}

Phosphorus (P) is a limiting element in freshwater systems. Excessive imports of P cause eutrophication (Ahlgren et al., 2005). Eutrophication of freshwater systems has become one of the most severe environmental problems in developing countries (PernetCoudrier et al., 2012). The issue is particularly serious in northern China, which is experiencing increasingly severe water shortages due to the rapid growth in population, industry and agriculture (Jiang, 2009). The consequences of eutrophication include algal blooms, oxygen depletion, aquatic ecosystem deterioration and increasing water treatment costs to ensure freshwater is suitable for human use (Vörösmarty et al., 2010).

\footnotetext{
* Corresponding author. Tel.: +86 10 62849817; fax: +86 1062849817 . E-mail addresses: bqshan@rcees.ac.cn, wenqiang100@aliyun.com (B. Shan).
}

The release of $\mathrm{P}$ from sediment is an important nutrient source that will induce continuous eutrophication in freshwater systems even if external inputs are reduced (Wu and Hua, 2014). Sediment $\mathrm{P}$ includes inorganic $\mathrm{P}(\mathrm{Pi})$ and organic $\mathrm{P}(\mathrm{Po})$. The mineralization of Po into Pi has a direct effect on P bioavailability in freshwater systems (Wang and Pant, 2010). However, until now, investigations of the species, concentrations, dynamics and effects of Po in sediment have been limited because of its complexity and limitations of analytical methods (Cade-Menun, 2005; Turner et al., 2005).

Phosphorus-31 nuclear magnetic resonance spectroscopy $\left({ }^{31} \mathrm{P}-\right.$ NMR) is a non-destructive, non-invasive technique for identifying chemical forms that has the advantage of enabling multiple $\mathrm{P}$ compounds to be characterized simultaneously with distinct binding properties (Cade-Menun, 2005). Several P compounds have been detected by ${ }^{31} \mathrm{P}-\mathrm{NMR}$, including phosphonates (phon-P), orthophosphate (ortho-P), orthophosphate monoesters (mono$\mathrm{P}$ ), orthophosphate diesters (diesters-P: lipid-P and DNA-P), 
pyrophosphates (pyro-P) and polyphosphates (poly-P) (Turner et al., 2005). Therefore, it is an ideal technique to analyze Po species in marine or freshwater sediments, as it will not only provide useful information pertaining to $\mathrm{P}$ biogeochemical cycling in aquatic environments, but will also yield sufficient insight into the identification of specific $P$ compounds.

The Haihe River is characterized by a high population density, rapid socioeconomic development and serious water pollution, caused by discharges of industrial and domestic wastewater. Because of the water shortages and the high nutrient $(\mathrm{P})$ inputs, the river is highly eutrophic. Therefore, the objectives of this study were to detect and analyze the P species in river sediments by $\mathrm{P}$ fractionation and ${ }^{31} \mathrm{P}-\mathrm{NMR}$, predict the $\mathrm{P}$ bioavailability.

\section{Materials and methods}

\subsection{Description of study area}

The Haihe River Basin is located in the north of China, and has an area of about $300,000 \mathrm{~km}^{2}$ and a population of 145 million. Beijing, Tianjin and many other cities are included in this river basin. The Fuyang River $\left(\mathrm{N} 36^{\circ} 23^{\prime}-38^{\circ} 14^{\prime}\right.$, E114 $\left.19^{\prime}-116^{\circ} 7^{\prime}\right)$ is an important tributary of the Haihe River System. It is $402 \mathrm{~km}$ long, and flows through the cities of Hengshui, Handan and Xingtai. Wagyanggou River, Shaocunpaigan River and Xiao River are three important tributaries of the Fuyang River. They receive large amounts of domestic wastewater from Shijiazhuang, the capital of Hebei Province. The Niuwei River is another important tributary of the Fuyang River system that mainly flows through Xingtai (Fig. 1). We chose the Fuyang River for sediment sampling because it is heavily polluted with $\mathrm{P}$ and it is representative of rivers in northern of China.

\subsection{Sample collection and analysis}

Water quality was monitored trimestral from 2010 to 2012. Sediment samples were collected in July 2012. Three surface (top $5 \mathrm{~cm}$ ) sediment samples were collected at each site using a Peterson grab sampler. Samples taken from the same site were pooled and homogenized to obtain a representative sample. All samples were frozen and stored at $-18^{\circ} \mathrm{C}$ immediately upon returning from the field.

The $\mathrm{pH}$ of sediment samples was determined on sediments suspended in deionized water at a sediment:water ratio of 1:2.5 (Bai et al., 2009). Organic matter (OM) in sediments was determined by loss of ignition at $550^{\circ} \mathrm{C}$ for $4 \mathrm{~h}$ (Jensen et al., 1992). Total Fe, $\mathrm{Al}, \mathrm{Mg}, \mathrm{Mn}$ and $\mathrm{Ca}$ were measured using ICP-OES after digesting sediments with $\mathrm{HNO}_{3}-\mathrm{HCl}-\mathrm{HF}$ (MARSXpress, CEM, USA), the ratio of $\mathrm{HNO}_{3}: \mathrm{HCl}$ was $3: 1(6 \mathrm{~mL})$, and then $2 \mathrm{~mL} \mathrm{HF}$ was added in the digesting tube. The limit of the ICP-OES was $0.1 \mathrm{mg} \mathrm{kg}^{-1}$. The recoveries varied, but all fell within the range of $90-95 \%$. Total $\mathrm{P}$ (TP) in sediments was determined by $1 \mathrm{~mol} \mathrm{~L}^{-1} \mathrm{HCl}$ extraction $(16 \mathrm{~h})$ after pretreatment for $2 \mathrm{~h}$ at $500^{\circ} \mathrm{C}$. Pi was determined by direct extraction with $1 \mathrm{~mol} \mathrm{~L}^{-1} \mathrm{HCl}(16 \mathrm{~h})$. Po concentrations in the sediments were calculated as the difference between TP and Pi (Aspila et al., 1976). TP in the surface water were analyzed using the molybdenum blue method after digestion by $\mathrm{K}_{2} \mathrm{~S}_{2} \mathrm{O}_{8}$ under high temperature $\left(120^{\circ} \mathrm{C}\right)$ and high pressure $\left(1.1 \mathrm{~kg} \mathrm{~cm}^{-2}\right)$ at least $30 \mathrm{~min}$, the limit of this method was $0.01 \mathrm{mg} \mathrm{L}^{-1}$ (Wei, 2002). An annual average TP concentration in surface water was calculated for each site by using monitoring data from 2010 to 2012. Three replicates were analyzed for each sampling event, from which the mean value was calculated.

\subsection{Phosphorus fractionations}

The $\mathrm{P}$ fractionation procedure was based on the method of Hieltjes and Lijklema (1980). This fractionation procedure separates the $\mathrm{P}$ in the sediment into five groups: (1) $\mathrm{P}$ in porewater and loosely sorbed $\mathrm{P}$ were extracted with $1 \mathrm{M} \mathrm{KCl}$ at room temperature for $1 \mathrm{~h}(\mathrm{KCl}-\mathrm{P})$, and then the sediment was shaking with $0.1 \mathrm{M} \mathrm{NaOH}$ for $17 \mathrm{~h}$ at room temperature, the extractant was determined using molybdenum blue method before $(\mathrm{NaOH}-\mathrm{Pi})$ and after (NaOH-TP) digestion by $\mathrm{K}_{2} \mathrm{~S}_{2} \mathrm{O}_{8}$. (2) The $\mathrm{NaOH}-\mathrm{Pi}$ was the $\mathrm{P}$ adsorbed to iron and manganese, and the difference between $\mathrm{NaOH}-\mathrm{TP}$ and $\mathrm{NaOH}-\mathrm{Pi}$ was (3) $\mathrm{NaOH}-\mathrm{Po}$, which was assumed to be Po and bacteria-incorporated P. Finally, (4) $\mathrm{H}_{2} \mathrm{SO}_{4}$ was used for extracting the $\mathrm{P}$ mostly apatite, which was stable withhold in the sediment $\left(\mathrm{H}_{2} \mathrm{SO}_{4}-\mathrm{P}\right)$. (5)The Res-P fraction was the difference between TP in sediment ( $\mathrm{HCl}$ extracted-P) and the sum of $\mathrm{KCl}-\mathrm{P}$, $\mathrm{NaOH}-\mathrm{TP}$ and $\mathrm{H}_{2} \mathrm{SO}_{4}-\mathrm{P}$. The P concentration in all the extracts was estimated colorimetrically using the method of Murphy and Riley (Murphy and Riley, 1962).

\subsection{NaOH-EDTA extraction and ${ }^{31} P-N M R$ analysis}

Sediment samples $(5.0 \mathrm{~g})$ were pre-treated for $16 \mathrm{~h}$ at room temperature with a $50-\mathrm{mL}$ solution of $0.05 \mathrm{~mol} \mathrm{~L}^{-1}$ EDTA and $0.25 \mathrm{~mol} \mathrm{~L}^{-1} \mathrm{NaOH}$ (Turner et al., 2003b). An aliquot of the $\mathrm{NaOH}-$ EDTA extract was used for Pi (Pi in NaOH-EDTA) and TP (TP in $\mathrm{NaOH}-\mathrm{EDTA}$ ) analyses using the molybdenum blue method before and after digestion with $\mathrm{K}_{2} \mathrm{~S}_{2} \mathrm{O}_{8}$. Po in the NaOH-EDTA extract was calculated as the difference between these two fractions. The $\mathrm{Fe}, \mathrm{Al}, \mathrm{Mg}, \mathrm{Mn}$ and $\mathrm{Ca}$ in the $\mathrm{NaOH}-\mathrm{EDTA}$ extract were measured using ICP-OES. The remaining solution was frozen and lyophilized to be used for ${ }^{31} \mathrm{P}-\mathrm{NMR}$ analysis.

The lyophilized $\mathrm{NaOH}-\mathrm{EDTA}$ extract $(0.3 \mathrm{~g})$ was re-dissolved in $0.6 \mathrm{~mL} \mathrm{D}_{2} \mathrm{O}$ and $0.1 \mathrm{~mL} 10 \mathrm{~mol} \mathrm{~L}^{-1} \mathrm{NaOH}$, ultrasonicated for $30 \mathrm{~min}$ and then equilibrated for $5 \mathrm{~min}$. $2 \%(\mathrm{v} / \mathrm{v})$ of bicarbonate buffered dithionite $\left(0.11 \mathrm{M} \mathrm{NaHCO}_{3}+0.11 \mathrm{M} \mathrm{Na}_{2} \mathrm{~S}_{2} \mathrm{O}_{4}\right)$ was added to the extract to reduce interference from paramagnetic ions, such as $\mathrm{Fe}$ and $\mathrm{Mn}$. The supernatants were centrifuged for $15 \mathrm{~min}$ at $14,000 \mathrm{rpm}$ and transferred to 5-mm NMR tubes. ${ }^{31} \mathrm{P}-\mathrm{NMR}$ spectra were obtained using a Bruker $400 \mathrm{MHz}$ spectrometer (Bruker, Billerica, MA, USA) operating at $129.53 \mathrm{MHz}$ at $25^{\circ} \mathrm{C}$. We used a $90^{\circ} \mathrm{C}$ observe pulse, a relaxation delay of $2 \mathrm{~s}$ and an acquisition time of $0.6 \mathrm{~s}$ (Liu et al., 2009). Spectra were collected with around 20,000 scans (Beijing NMR Center, Beijing, China). Chemical shifts were recorded relative to an $85 \% \mathrm{H}_{3} \mathrm{PO}_{4}$ standard ( $\left.\delta=0 \mathrm{ppm}\right)$. Signals were assigned to $\mathrm{P}$ species based on data in the literature (Cade-Menun, 2005; Turner et al., 2003a). The peak area was determined by visual inspection and an automated peak analysis tool. For the different $\mathrm{P}$ species areas, the contribution of each P compound group was calculated relative to the TP in the NaOH-EDTA extraction, determined by molybdenum blue method (Zhang et al., 2013). All NMR-spectra showed peaks in the area of phon-P (12 to $23 \mathrm{ppm}$ ), ortho-P (6 to $7 \mathrm{ppm}$ ), mono-P (4 to $6 \mathrm{ppm}$ ), lipid-P (1 to $3 \mathrm{ppm})$, DNA-P (0 ppm), pyro-P $(-3.5$ to $-4.5 \mathrm{ppm})$ and poly-P $(-17$ to $-19 \mathrm{ppm}$ ) (Cade-Menun, 2005; Turner et al., 2003a).

\section{Results}

\subsection{Phosphorus in surface water and sediment samples}

Sediment properties are shown in Table 1. The concentration of TP varied greatly, and ranged from 462 to $9829 \mathrm{mg} \mathrm{kg}^{-1}$. Pi was the main $\mathrm{P}$ fraction. Po concentrations ranged from 22 to $2040 \mathrm{mg} \mathrm{kg}^{-1}$, accounting for between 4.8 and $51.3 \%$ of TP. OM 


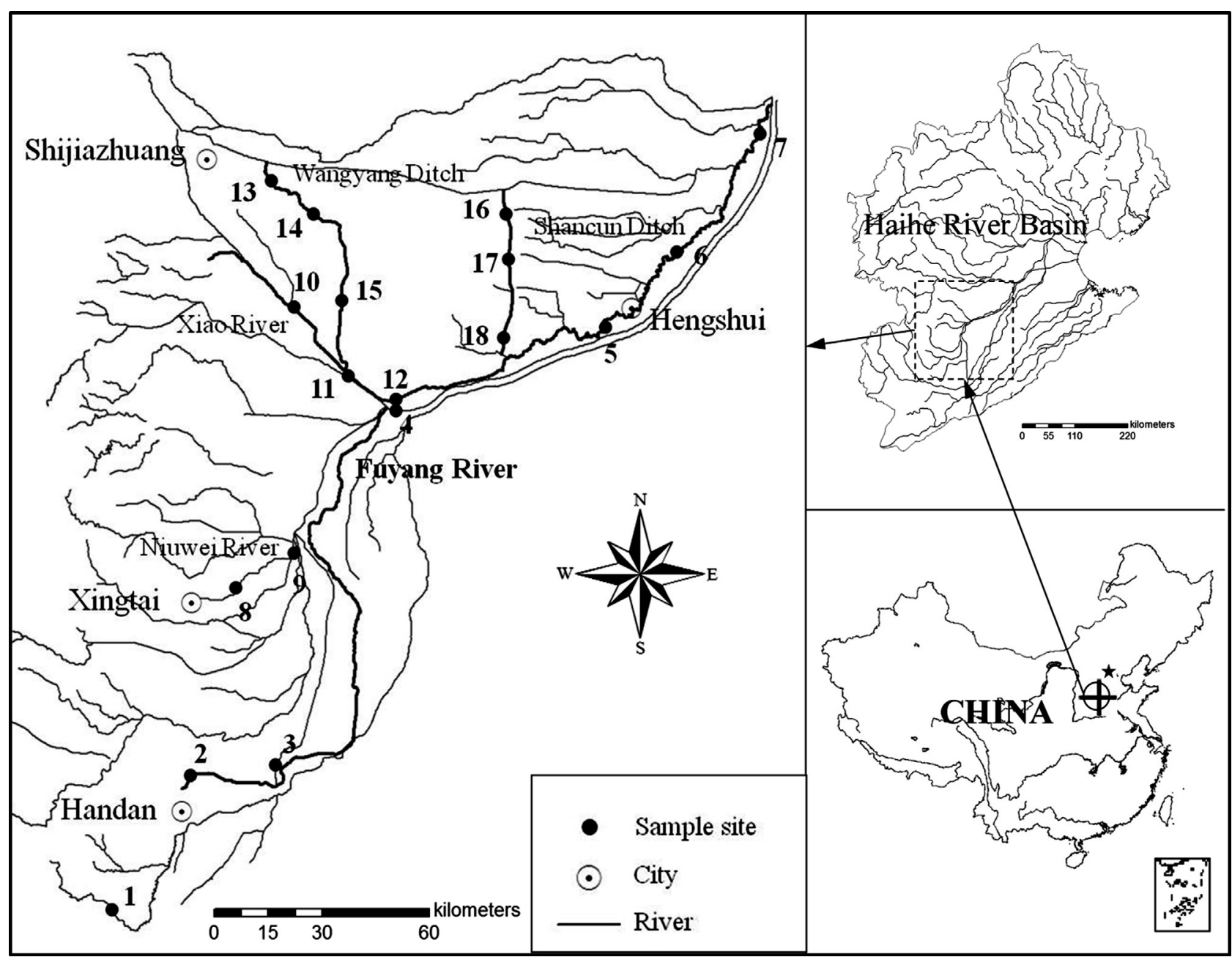

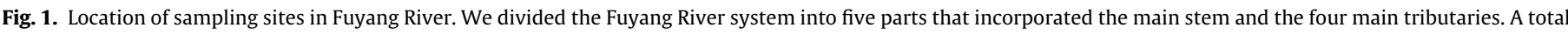

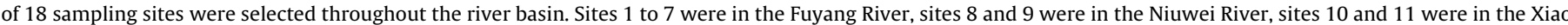
River, sites 12 to 15 were in the Wangyanggou River and sites 16 to 18 were in the Shaocunpaigan River.

Table 1

Physical and chemical properties of sediments in Fuyang River.

\begin{tabular}{|c|c|c|c|c|c|c|c|c|c|c|c|}
\hline \multirow[t]{2}{*}{ River } & \multirow[t]{2}{*}{ Site } & \multirow{2}{*}{$\begin{array}{l}\mathrm{OM} \\
(\%)\end{array}$} & \multirow[t]{2}{*}{$\mathrm{C} / \mathrm{P}$} & \multirow[t]{2}{*}{$\mathrm{pH}$} & \multicolumn{7}{|l|}{ Sediment } \\
\hline & & & & & $\begin{array}{l}\text { TP } \\
\left(\mathrm{mg} \mathrm{kg}^{-1}\right)\end{array}$ & $\begin{array}{l}\text { Po (\%) } \\
\left(\mathrm{mg} \mathrm{kg}^{-1}\right)\end{array}$ & $\begin{array}{l}\mathrm{Al} \\
\left(\mathrm{g} \mathrm{kg}^{-1}\right)\end{array}$ & $\begin{array}{l}\mathrm{Ca} \\
\left(\mathrm{g} \mathrm{kg}^{-1}\right)\end{array}$ & $\begin{array}{l}\mathrm{Fe} \\
\left(\mathrm{g} \mathrm{kg}^{-1}\right)\end{array}$ & $\begin{array}{l}\mathrm{Mg} \\
\left(\mathrm{g} \mathrm{kg}^{-1}\right)\end{array}$ & $\begin{array}{l}\mathrm{Mn} \\
\left(\mathrm{g} \mathrm{kg}^{-1}\right)\end{array}$ \\
\hline \multirow[t]{7}{*}{ Fuyang River } & 1 & 6.55 & 44.38 & 7.65 & 1186 & $274(23.1)$ & 32.51 & 13.38 & 30.06 & 2.95 & 0.38 \\
\hline & 2 & 8.47 & 21.07 & 7.84 & 3848 & $547(14.2)$ & 5.51 & 25.80 & 42.42 & 5.26 & 0.53 \\
\hline & 3 & 6.44 & 27.10 & 7.35 & 1338 & $210(15.7)$ & 28.43 & 20.97 & 42.50 & 3.13 & 0.63 \\
\hline & 4 & 25.19 & 14.37 & 7.17 & 9829 & 3787 (38.5) & 17.35 & 14.78 & 44.72 & 4.05 & 0.57 \\
\hline & 5 & 4.87 & 41.04 & 7.54 & 734 & $160(21.8)$ & 18.21 & 15.29 & 36.27 & 3.88 & 0.57 \\
\hline & 6 & 20.81 & 25.62 & 8.27 & 4190 & $2109(50.3)$ & 7.18 & 11.17 & 55.54 & 5.53 & 0.52 \\
\hline & 7 & 3.27 & 28.05 & 8.06 & 720 & $88(12.3)$ & 18.81 & 12.95 & 41.02 & 3.89 & 0.65 \\
\hline \multirow[t]{2}{*}{ Niuwei River } & 8 & 4.03 & 32.10 & 7.43 & 733 & $87(11.8)$ & 32.59 & 18.26 & 32.78 & 3.81 & 0.40 \\
\hline & 9 & 11.28 & 35.62 & 6.69 & 2048 & $569(27.8)$ & 22.41 & 13.12 & 45.29 & 5.58 & 0.30 \\
\hline \multirow[t]{2}{*}{ Xiao River } & 10 & 5.67 & 26.32 & 7.73 & 1460 & $301(20.6)$ & 35.19 & 18.42 & 34.77 & 4.62 & 0.43 \\
\hline & 11 & 5.43 & 41.24 & 7.48 & 818 & $145(17.7)$ & 34.57 & 14.16 & 45.90 & 4.07 & 0.41 \\
\hline Wangyanggou & 12 & 20.69 & 17.24 & 6.95 & 7366 & $3686(50.0)$ & 9.89 & 20.49 & 36.74 & 5.26 & 0.56 \\
\hline \multirow[t]{3}{*}{ River } & 13 & 2.87 & 33.54 & 8.53 & 574 & $96(16.7)$ & 15.27 & 20.29 & 33.46 & 4.25 & 0.58 \\
\hline & 14 & 2.78 & 33.69 & 7.84 & 462 & $22(4.8)$ & 27.15 & 23.52 & 37.44 & 4.60 & 0.46 \\
\hline & 15 & 9.83 & 19.75 & 7.75 & 3060 & $1570(51.3)$ & 19.60 & 20.89 & 30.88 & 5.18 & 0.45 \\
\hline Shaocunpaigan & 16 & 5.69 & 51.40 & 8.02 & 935 & $200(21.3)$ & 20.20 & 12.70 & 34.69 & 3.48 & 0.49 \\
\hline \multirow[t]{2}{*}{ River } & 17 & 1.99 & 25.88 & 8.52 & 534 & $51(9.6)$ & 27.08 & 21.97 & 32.69 & 4.59 & 0.49 \\
\hline & 18 & 12.09 & 15.78 & 7.25 & 4228 & $2134(50.5)$ & 27.12 & 14.15 & 57.59 & 3.90 & 0.63 \\
\hline
\end{tabular}

Parentheses indicate the proportion of Po to TP in sediments (\%). 
content varied with TP concentrations. The average OM content was $8.78 \%$ and ranged from 1.99 to $25.19 \%$. The $\mathrm{pH}$ in sediments ranged from 6.69 to 8.53. The concentrations of other metals in the sediments were as follows: total $\mathrm{Al}$ concentrations ranged from 5.51 to $35.19 \mathrm{~g} \mathrm{~kg}^{-1}$, total Ca from 11.17 to $25.8 \mathrm{~g} \mathrm{~kg}^{-1}$, total $\mathrm{Fe}$ from 30.06 to $57.59 \mathrm{~g} \mathrm{~kg}^{-1}$, total $\mathrm{Mg}$ from 2.95 to $5.58 \mathrm{~g} \mathrm{~kg}^{-1}$ and total Mn from 0.30 to $0.65 \mathrm{~g} \mathrm{~kg}^{-1}$. The ratio of TC to TP in the sediments ranged from 14.37 to 51.40 . Total $\mathrm{P}$ and soluble reactive phosphorus (SRP) in surface water samples was ranging from 0.17 to $7.29 \mathrm{mg} \mathrm{L}^{-1}$ and 0.06 to $6.44 \mathrm{mg} \mathrm{L}^{-1}$, respectively.

\subsection{Phosphorus fractionation in sediments}

Sediment P was mainly composed of $\mathrm{H}_{2} \mathrm{SO}_{4}-\mathrm{P}$ and $\mathrm{NaOH}-\mathrm{Pi}$. $\mathrm{H}_{2} \mathrm{SO}_{4}-\mathrm{P}$ concentrations ranged from 344.4 to $2941.7 \mathrm{mg} \mathrm{kg}^{-1}$, and had a relative contribution of between 20.2 and $74.5 \%$ to TP, while concentrations of $\mathrm{NaOH}-\mathrm{Pi}$ ranged from 54.4 to $5749.2 \mathrm{mg} \mathrm{kg}^{-1}$ and had a relative contribution of 7.6 to $65.1 \%$ to TP. Res-P ranged from 33.6 to $1257.9 \mathrm{mg} \mathrm{kg}^{-1}$, and had a relative contribution of 1.4 to $18.8 \%$. NaOH-Po ranged from 0.3 to $243.9 \mathrm{mg} \mathrm{kg}^{-1}$, and had a relative contribution of between 0.1 and $5.2 \%$ to TP, while $\mathrm{KCl}-\mathrm{P}$ ranged from 1.2 to $31.0 \mathrm{mg} \mathrm{kg}^{-1}$, and had a relative contributions of between 0.1 and $2.1 \%$ to TP. The rank order and average relative proportions of the $\mathrm{P}$ fractions were as follows (the proportion was based on the average proportion of the $\mathrm{KCl}-\mathrm{P}): \mathrm{H}_{2} \mathrm{SO}_{4}-\mathrm{P}(69.7 \%)>\mathrm{NaOH}-\mathrm{Pi}(47.5 \%)>$ Res-P $(15.9 \%)>\mathrm{NaOH}-\mathrm{Po}(2.9 \%)>\mathrm{KCl}-\mathrm{P}(1.0 \%)$.

\section{3. ${ }^{31} \mathrm{P}-\mathrm{NMR}$ spectra of NaOH-EDTA extracts of sediments}

The NMR spectra of the surface sediments are shown in Fig. 2. Seven $\mathrm{P}$ compounds were detected in the $\mathrm{NaOH}-\mathrm{EDTA}$ extract by ${ }^{31} \mathrm{P}-\mathrm{NMR}$. The concentrations of the various $\mathrm{P}$ compound groups in surface sediments are presented in Table 2. TP in the NaOH-EDTA extracts ranged from 179.7 to $5712.9 \mathrm{mg} \mathrm{kg}^{-1}$, which represented recovery of between 27.2 and $87.1 \%$ of the TP in the sediments. Po in the NaOH-EDTA ranged from 15.4 to $2578.3 \mathrm{mg} \mathrm{kg}^{-1}$, representing a recovery ranging from 30.0 to $73.0 \%$. In the NaOH-EDTA extracts, ortho-P was the main component of TP, which ranged from 140.8 to $4061.6 \mathrm{mg} \mathrm{kg}^{-1}$, accounting for 45.2 to $92.4 \%$ of TP. Pyro-P ranged from 0.3 to $44.2 \mathrm{mg} \mathrm{kg}^{-1}$, accounting for 0.1 to $6.6 \%$ of the TP. Poly-P was only detected in sediments from site 1 , and had a concentration of $0.2 \mathrm{mg} \mathrm{kg}^{-1}$ and a relative contribution of $0.04 \%$ to TP. Mono-P was the main component of Po, which ranged from 13.1 to $2220.9 \mathrm{mg} \mathrm{kg}^{-1}$, accounting for between 6.6 and $45.7 \%$ of TP. Lipid$P$ ranged from 0 to $141.1 \mathrm{mg} \mathrm{kg}^{-1}$, accounting for 0 to $2.7 \%$ of the TP. DNA-P ranged from 0.5 to $124.2 \mathrm{mg} \mathrm{kg}^{-1}$, accounting for 0.3 to $3.9 \%$ of the TP. The levels of phon-P ranged from 0 to $141.4 \mathrm{mg} \mathrm{kg}^{-1}$, accounting for up to $3.3 \%$ of TP.

\section{Discussion}

\subsection{Sediment P pollution}

The Haihe River basin has high population, economic and agricultural growth rates, and as a result, faces increasingly severe water-related issues. Human and industrial water consumption and irrigation of intensely farmed land has led to water shortages. Meanwhile, the nutrient concentrations in this region's rivers have increased dramatically in the past 40 years (Pernet-Coudrier et al., 2012). The average and maximum TP concentrations in surface water were 1.68 and $7.29 \mathrm{mg} \mathrm{L}^{-1}$, while the average and maximum SRP concentrations were 1.21 and $6.44 \mathrm{mg} \mathrm{L}^{-1}$, respectively. All of these values far exceed the water quality criteria for both the USA $\left(0.1 \mathrm{mg} \mathrm{L}^{-1}\right.$ : US EPA. Quality criteria for water1986, EPA 440/5-86-001) and China (0.4 $\mathrm{mg} \mathrm{L}^{-1}$ : National Standard of the People's Republic of China, Environmental quality standards for surface water, GB3838-2002), which means that the water is unsuitable for any use. Sediment TP concentrations ranged from 462 to $9829 \mathrm{mg} \mathrm{kg}^{-1}$. The average sediment TP concentration was $2448 \mathrm{mg} \mathrm{kg}^{-1}$ and TP concentrations exceeded $1000 \mathrm{mg} \mathrm{kg}^{-1}$ at $55.6 \%$ of sampling sites. Because of the excessive $\mathrm{P}$ inputs, significant amounts of $\mathrm{P}$ have accumulated in the river sediments, and exceed what has been reported for Bronx River (Wang and Pant, 2010), Yellow River (Pan et al., 2013), Illinois River (Haggard and Soerens, 2006) and Amazon River (Berner and Rao, 1994).

The ratio of TC to TP $(C / P)$ gives information on the origin of the OM and the Po biogeochemical cycle (Zhang, 2007). A high C/P value implies $P$ losses. Po degrades when $O M$ degrades. A low $C / P$ value means that the $\mathrm{P}$ input is mainly from human activities and that $P$ is accumulating in the sediments. In this study, a negative correlation between the $C / P$ values and TP in the sediments indicated that the high TP concentrations were mainly due to anthropogenic inputs. Correlations between TP and OM $\left(R^{2}\right.$ TP-OM $\left.=0.87\right)$ and Po and $\mathrm{OM}\left(R_{\mathrm{Po}-\mathrm{OM}}^{2}=0.89\right)$ indicated that the $\mathrm{P}$ and $\mathrm{OM}$ in the sediments are homologous, and that the majority of Po was most likely associated with OM, such as fulvic and humic acids (Bai et al., 2009). High values of TP and Po appeared in the Fuyang River. The concentrations of TP and Po were 9829 and $3787 \mathrm{mg} \mathrm{kg}^{-1}$ at sampling point 4 , the location of the Aixinzhuang Dam. The dam interferes with river flow and reduces velocity, which results in sediment $P$ accumulation at the dam wall.

\section{2. ${ }^{31} P$-NMR spectroscopy and $P$ fractions}

Ortho-P was the dominant $\mathrm{P}$ fraction in $\mathrm{NaOH}-\mathrm{EDTA}$ extracts of the river sediments. This could be because of the continuous inputs of either industrial and domestic wastewater, or non-point pollution from agriculture. A proportion of the ortho-P may also be the result of in-river transformations. For example, some Po that entered the river systems may have been hydrolyzed to ortho-P by phosphatase (Turner et al., 2006). Mono-P were the main form of Po in the sediments. It represents a wide range of important Po compounds, such as inositol phosphate and sugar phosphates, and has a long half-life in sediments (23 years) (Ahlgren et al., 2005). The ortho-P may originated from sediment (e.g. Inositol hexaphosphate) or the degradation of diesters. In this study, we also found that the residual $\mathrm{P}$ fraction was positively correlated with the mono-P and phon-P fractions, which ranged from 6.57 to $29.20 \%$ of $\mathrm{TP}$ in the $\mathrm{NaOH}-\mathrm{EDTA}$ extracts $\left(R^{2}=0.79, p<0.01\right)$. Diesters-P were a form of labile $P$ in the sediments. It has a half-life of 21 years, and is a mixture of compounds such as DNA-P, lipid-P and teichoic-P (Cade-Menun, 2005; Turner et al., 2003b). A positive correlation between diester-P in $\mathrm{NaOH}-\mathrm{EDTA}$ and the $\mathrm{NaOH}-\mathrm{Po}$ in sediment by $\mathrm{P}$ fractionation indicated that the $\mathrm{NaOH}-\mathrm{Po}$ by $\mathrm{P}$ fractionation was mostly labile $\mathrm{P}\left(R^{2}=0.77, p<0.01\right)$.

The positive correlation between $\mathrm{NaOH}-\mathrm{Pi}$ (as determined by $\mathrm{P}$ fractionation) and $\mathrm{NaOH}-\mathrm{Fe}$ and $\mathrm{NaOH}-\mathrm{Al}$ indicated that the sediment $\mathrm{P}$ immobilization potential was controlled by $\mathrm{Fe}$ and $\mathrm{Al}$ hydroxides $\left(R^{2}=0.88, p<0.01\right)$ (Kopáček et al., 2005). Liu reported that $\mathrm{BD}-\mathrm{Fe}$ and $\mathrm{NaOH}-\mathrm{Al}$ together explained $68 \%$ of the variability in the maximum sorption capacity of sediment (Liu et al., 2009). $\mathrm{P}$ fractionation and ${ }^{31} \mathrm{P}-\mathrm{NMR}$ analysis showed that $35 \%$ of Pi was labile $\mathrm{P}$, including $\mathrm{KCl}-\mathrm{P}$ and $\mathrm{NaOH}-\mathrm{Pi}$ (Fe-P and $\mathrm{Al}-\mathrm{P}$ ). Biogenic-P, which was considered molybdenum-non-reactive $\mathrm{P}$ in the $\mathrm{NaOH}$ extract, accounted for $24 \%$ in the sediments. There is a high risk of 
Table 2

Concentrations ${ }^{\ddagger \ddagger}$ of $\mathrm{P}$ compounds in NaOH-EDTA extracts of the sediments determined by solution ${ }^{31} \mathrm{P}$-NMR

\begin{tabular}{|c|c|c|c|c|c|c|c|c|c|c|}
\hline \multirow[t]{2}{*}{ River } & \multirow[t]{2}{*}{ Site } & \multirow[t]{2}{*}{ TP } & \multirow{2}{*}{$\begin{array}{l}\text { Po } \\
\text { (\%) }\end{array}$} & \multicolumn{3}{|l|}{ Inorganic $\mathrm{P}$} & \multicolumn{4}{|l|}{ Organic $\mathrm{P}$} \\
\hline & & & & $\begin{array}{l}\text { Ortho-P } \\
\left(\mathrm{mg} \mathrm{kg}^{-1}\right)\end{array}$ & $\begin{array}{l}\text { Pyro-P (mg } \\
\left.\mathrm{kg}^{-1}\right)\end{array}$ & $\begin{array}{l}\text { Poly-P (mg } \\
\left.\mathrm{kg}^{-1}\right)\end{array}$ & $\begin{array}{l}\text { Mono-P } \\
\left(\mathrm{mg} \mathrm{kg}^{-1}\right)\end{array}$ & $\begin{array}{l}\text { Lipid-P (mg } \\
\left.\mathrm{kg}^{-1}\right)\end{array}$ & $\begin{array}{l}\text { DNA-P (mg } \\
\left.\mathrm{kg}^{-1}\right)\end{array}$ & $\begin{array}{l}\text { Phon-P (mg } \\
\left.\mathrm{kg}^{-1}\right)\end{array}$ \\
\hline \multirow[t]{7}{*}{ Fuyang River } & 1 & 512.7 & $129.1(47.1)^{*}$ & $389.5(75.9)^{* *}$ & $33.7(6.6)$ & $0.2(0.04)$ & $66.7(13.0)$ & $4.2(0.8)$ & $18.4(3.6)$ & n.d. \\
\hline & 2 & 2731.9 & $377.7(69.0)$ & $2340.5(85.7)$ & $20.8(0.8)$ & n.d. & $241.5(8.8)$ & $23.9(0.9)$ & $65.3(2.4)$ & $39.9(1.5)$ \\
\hline & 3 & 857.7 & $113.0(53.7)$ & $746.8(87.1)$ & $6.2(0.7)$ & n.d. & $79.2(9.2)$ & $6.5(0.8)$ & $16.2(1.9)$ & $2.9(0.3)$ \\
\hline & 4 & 5712.9 & $1657.3(43.8)$ & $4061.6(71.1)$ & $44.2(0.8)$ & n.d. & $1260.6(22.1)$ & $141.1(2.5)$ & $124.2(2.2)$ & $81.3(1.4)$ \\
\hline & 5 & 314.1 & $94.3(58.8)$ & $256.9(81.8)$ & $3.1(0.9)$ & n.d. & $39.8(12.7)$ & $1.8(0.6)$ & $12.4(3.9)$ & n.d. \\
\hline & 6 & 3299.4 & $1222.5(58.0)$ & $2056.8(62.3)$ & $41.3(1.3)$ & n.d. & $963.4(29.2)$ & $31.2(0.9)$ & $110.9(3.4)$ & $95.7(2.9)$ \\
\hline & 7 & 195.7 & $64.2(72.8)$ & $172.6(88.2)$ & $1.1(0.5)$ & n.d. & $19.9(10.2)$ & n.d. & $2.2(1.1)$ & n.d. \\
\hline \multirow[t]{2}{*}{ Niuwei River } & 8 & 357.5 & $55.5(64.0)$ & $330.2(92.4)$ & $0.8(0.2)$ & n.d. & $23.5(6.6)$ & n.d. & $3.1(0.9)$ & n.d. \\
\hline & 9 & 1607.3 & $388.8(68.3)$ & $1237.2(76.9)$ & $8.3(0.5)$. & n.d. & $325.6(20.3)$ & $6.5(0.4)$ & $22.2(1.4)$ & $7.6(0.5)$ \\
\hline \multirow{2}{*}{ Xiao River } & 10 & 1008.2 & $219.7(73.0)$ & $786.9(78.1)$ & $13.7(1.4)$ & n.d. & $181.3(17.9)$ & $2.9(0.3)$ & 20.1 (1.9) & $3.3(0.3)$ \\
\hline & 11 & 487.3 & $52.8(36.5)$ & $427.2(87.7)$ & $1.1(0.2)$ & n.d. & $55.6(11.4)$ & $0.6(0.1)$ & $1.6(0.3)$ & $1.2(0.2)$ \\
\hline Wangyanggou & 12 & 4860.1 & $2578.3(70.0)$ & $2194.9(45.2)$ & $41.8(0.9)$ & n.d. & 2220.9 (45.7) & $133.2(2.7)$ & $121.9(2.5)$ & $147.4(3.0)$ \\
\hline \multirow[t]{3}{*}{ River } & 13 & 186.4 & $28.8(30.0)$ & $154.4(82.8)$ & $0.3(0.1)$ & n.d. & $31.1(16.7)$ & n.d. & $0.5(0.3)$ & $0.1(0.1)$ \\
\hline & 14 & 157.6 & $15.4(70.1)$ & $140.8(89.4)$ & $0.3(0.2)$ & n.d. & $13.1(8.3)$ & $0.6(0.4)$ & $1.9(1.3)$ & $0.9(0.6)$ \\
\hline & 15 & 2171.9 & $755.9(48.0)$ & $1394.4(64.2)$ & $36.9(1.7)$ & n.d. & $539.1(24.8)$ & $53.4(2.5)$ & $75.6(3.5)$ & $72.5(3.3)$ \\
\hline Shaocunpaigan & 16 & 487.9 & $123.0(61.6)$ & $362.9(74.4)$ & $4.6(0.9)$ & n.d. & $104.6(21.4)$ & $1.9(0.4)$ & $10.9(2.3)$ & $2.8(0.6)$ \\
\hline \multirow[t]{2}{*}{ River } & 17 & 179.7 & $24.1(47.1)$ & $161.7(90.0)$ & $0.8(0.4)$ & n.d. & $15.1(8.4)$ & n.d. & $2.1(1.2)$ & n.d. \\
\hline & 18 & 3684.5 & $1199.5(56.2)$ & $2527.5(68.6)$ & $32.8(0.9)$ & n.d. & $1009.2(27.4)$ & $14.5(0.4)$ & $92.5(2.5)$ & $8.2(0.2)$ \\
\hline
\end{tabular}

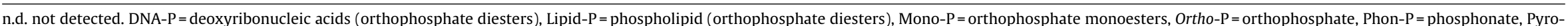

$\mathrm{P}=$ pyrophosphates, Poly- $\mathrm{P}=$ polyphosphates.

The value was calculated from the concentration in the $\mathrm{NaOH}-\mathrm{EDTA}$ extract and the dry weight.

" The proportion of Po in NaOH-EDTA extraction to total Po in sediments (\%)

The proportion of individual P fraction to total P in NaOH-EDTA extraction. 


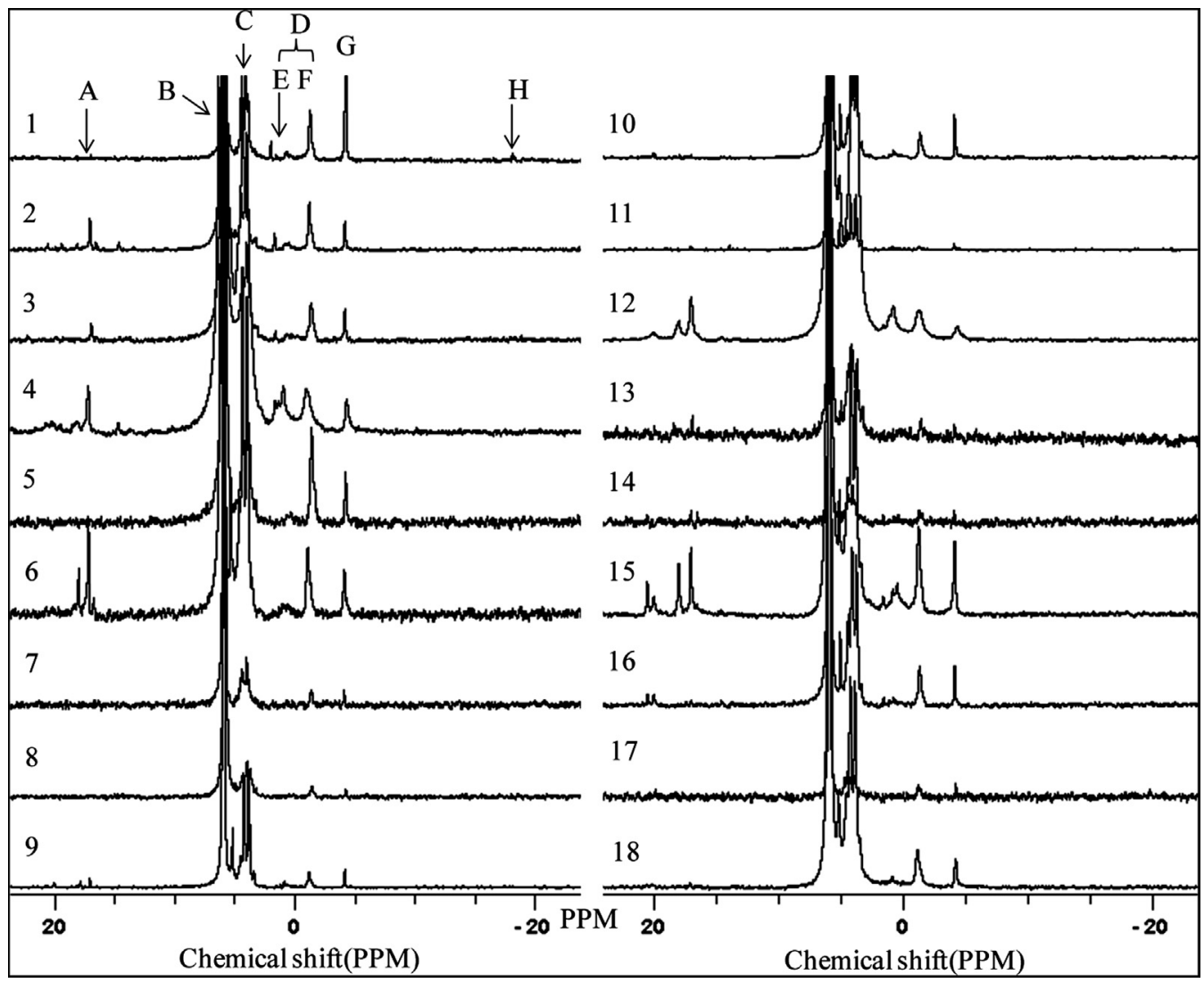

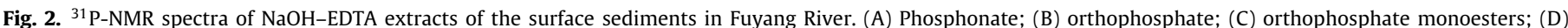

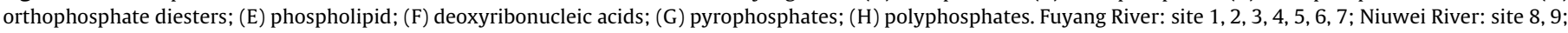
Xiao River: 10, 11; Wangyanghou River: 12, 13, 14, 15; Shaocunpaigan River: 16, 17, 18.

release of both labile P and biogenic-P to the water column, thereby leading to water eutrophication.

Apart from ortho-P, biogenic $\mathrm{P}$ is an important source of $\mathrm{P}$ in surface water. Biogenic $P$ includes Po, poly-P and pyro-P, which were analyzed as molybdenum-non-reactive $\mathrm{P}$ in the $\mathrm{NaOH}$ extract (Ahlgren et al., 2005). Biogenic P could be released from the sediments under redox conditions and could induce water eutrophication (Qian et al., 2011). The positive relationship between biogenic-P and TP in the water column indicates that the biogenic-P compounds could be released into surface water and could support hydrophyte growth (Wang and Pant, 2010).

\section{Conclusions}

This research has used $\mathrm{P}$ fractionation and ${ }^{31} \mathrm{P}-\mathrm{NMR}$ to provide an insight into the $P$ species and distribution of $P$ pollution in sediments of the heavily polluted and water scarce Fuyang River and their effects. Results show that the river sediments have accumulated significant amounts of $\mathrm{Pi}$ and Po. Sediment $\mathrm{P}$ was mainly composed of $\mathrm{H}_{2} \mathrm{SO}_{4}-\mathrm{P}$ and $\mathrm{NaOH}-\mathrm{Pi}$. Seven $\mathrm{P}$ compounds were detected in $\mathrm{NaOH}-$ EDTA extract from the ${ }^{31} \mathrm{P}-\mathrm{NMR}$ analysis. Ortho$P$ and mono-P were the dominant forms, while smaller amounts of pyro-P, DNA-P, phon-P, lipid-P and poly-P were found in the surface sediments. Results of the $P$ fractionation and ${ }^{31} \mathrm{P}-\mathrm{NMR}$ analysis showed that biogenic-P accounted for $24 \%$ of $\mathrm{P}$ in the sediments.

\section{Acknowledgments}

We thank Dr. Jingxin Yang and Dr. Hongwei Li for ${ }^{31}$ P-NMR analysis (Beijing Nuclear Magnetic Resonance Center). This work was supported by the National Natural Science Foundation of China (Grant No. 20907067 and 21107126), the National Water Pollution Control and Management Technology Major Projects of China (2012ZX07203-006 and 2012ZX07203-003) and the Open Fund of Key Laboratory of Contaminated Environment Control and Regional Ecology Safety (SYU-KF-L-07), Open Fund of Key Laboratory of Regional Environment Eco-remediation, Education Ministry (SYUKF-E-07).

\section{References}

Ahlgren, J., Tranvik, L., Gogoll, A., Waldeback, M., Markides, K., Rydin, E., 2005. Sediment depth attenuation of biogenic phosphorus compounds measured by ${ }^{31} \mathrm{P}$ NMR. Environ. Sci. Technol. 39, 867-872.

Aspila, K.I., Agemian, H., Chau, A.S.Y., 1976. A Semi-automated method for the determination of inorganic organic and total phosphate in sediments. Analyst 101, 187-197.

Bai, X.L., Ding, S.M., Fan, C.X., Liu, T., Shi, D., Zhang, L., 2009. Organic phosphorus species in surface sediments of a large shallow, eutrophic lake, Lake Taihu, China. Environ. Pollut. 157, 2507-2513.

Berner, R.A., Rao, J.L., 1994. Phosphorus in sediments of the Amazon River and estuary: implications for the global flux of phosphorus to the sea. Geochim. Cosmochim. Acta 58, 2333-2339.

Cade-Menun, B.J., 2005. Characterizing phosphorus in environmental and agricultural samples by ${ }^{31} \mathrm{P}$ nuclear magnetic resonance spectroscopy. Talanta 66 , 359-371.

Haggard, B.E., Soerens, T.S., 2006. Sediment phosphorus release at a small impoundment on the Illinois River, Arkansas and Oklahoma, USA. Ecol. Eng. 28, 280-287.

Hieltjes, A.H.M., Lijklema, L., 1980. Fractionation of inorganic phosphorus in calcareous sediments. J. Environ. Qual. 9, 405-407.

Jiang, Y., 2009. China water scarcity. J. Environ. Manage. 90, 3185-3196.

Jensen, H.S., Kristensen, P., Jeppesen, E., Skytthe, A., 1992. Iron:phosphorus ratio in surface sediment as an indicator of phosphate release from aerobic sediments in shallow lakes. Hydrobiologia 235/236, 731-743.

Kopáček., J., Borovec, J., Hejzlar, J., Ulrich, K., Norton, S.A., Amirbahman, A., 2005. Aluminum control of phosphorus sorption by lake sediments. Environ. Sci. Technol. $39,8784-8789$. 
Liu, J.Y., Wang, H., Yang, H.J., Ma, Y.J., Cai, O.C., 2009. Detection of phosphorus species in sediments of artificial landscape lakes in China by fractionation and phosphorus-31 nuclear magnetic resonance spectroscopy. Environ. Pollut. 157, 49-56.

Murphy, J., Riley, J.P., 1962. A modified single solution method for the determination of phosphate in nature waters. Anal. Chim. Acta 27, 31-36.

Pan, G., Krom, M.D., Zhang, M.Y., Zhang, X.W., Wang, L.J., Dai, L.C., Shen, Y.Q. Mortimer, J.G., 2013. Impact of suspended inorganic particles on phosphorus cycling in the Yellow River (China). Environ. Sci. Technol. 47, 9685-9692.

Pernet-Coudrier, B., Qi, W.X., Liu, H.J., Müller, B., Berg, M., 2012. Sources and pathways of nutrients in the semi-arid region of Beijing-Tianjin, China. Environ. Sci. Technol. 46, 5294-5301.

Qian, Y.C., Liang, X.Q., Chen, Y.X., Lou, L.P., Cui, X.Y., Tang, J., Li, P.F., Cao, R.K., 2011. Significance of biological effects on phosphorus transformation processes at the water-sediment interface under different environmental conditions. Ecol. Eng. 37, 815-825.

Turner, B.L., Cade-Menun, B.J., Condron, L.M., Newman, S., 2005. Extraction of soil organic phosphorus. Talanta 66, 294-306.

Turner, B.L., Mahieu, N., Condron, L.M., 2003a. The phosphorus composition of temperate pasture soils determined by $\mathrm{NaOH}-$ EDTA extraction and solution ${ }^{31} \mathrm{P}$ NMR spectroscopy. Org. Geochem. 34, 1199-1210.
Turner, B.L., Mahieu, N., Condron, L.M., 2003b. Phosphorus-31 nuclear magnetic resonance spectral assignments of phosphorus compounds in soil $\mathrm{NaOH}-\mathrm{EDTA}$ extracts. Soil Sci. Soc. Am. J. 67, 497-510.

Turner, B.L., Newman, S., Newman, J.M., 2006. Organic phosphorus sequestration in subtropical treatment wetlands. Environ. Sci. Technol. 40, 727-733.

Vörösmarty, C.J., McIntyre, P.B., Gessner, M.O., Dudgeon, D., Prusevich, A., Green, P. Glidden, S., Bunn, S.E., Sullivan, C.A., Liermann, C.R., Davies, P.M., 2010. Global threats to human water security and river biodiversity. Nature 467, 555-561.

Wang, J.Y., Pant, H.K., 2010. Enzymetic hydrolysis of organic phosphorus in river bed sediments. Ecol. Eng. 36, 963-968.

Wei, F.S., 2002. Water and Wastewater Monitoring Analysis Method. China Environment Science Press, Beijing, pp. 246.

Wu, D., Hua, Z.L., 2014. The effect of vegetation on sediment resuspension and phosphorus release under hydrodynamic disturbance in shallow lakes. Ecol. Eng. 69, 55-62.

Zhang, R.Y., 2007. Geochemical Characteristics of Organic Phosphorus in the Lake Sediments and its Effects on Lake Eutrophication: A Case Study of Lake Taihu, Lake Hongfeng, Lake Baihua and Lake Erhai in China. University of Chinese Academy of Science.

Zhang, W.Q., Shan, B.Q., Zhang, H., Tang, W.Z., 2013. Assessment of preparation methods for organic phosphorus analysis in phosphorus-polluted Fe/Al-rich Haihe River Sediments using solution ${ }^{31}$ P-NMR. PLoS One 8 (10), e76525. 